\title{
Influence of Strategic Marketing Approaches in Business Communication
}

\author{
Stavros Kalogiannidis, Adjunct Lecturer \\ Department of Business Administration \\ University of Western Macedonia, Greece \\ E-mail: stavroskalogiannidis@gmail.com \\ ORCiD: https://orcid.org/0000-0002-2337-5775
}

\author{
Stamatis Kontsas, Assistant Professor \\ Department of Business Administration \\ University of Western Macedonia, Greece \\ E-mail: skontsas@uowm.gr
}

Olympia Papaevangelou

Secondary \& Postsecondary Educator

Ministry of Education, Kozani, Greece

E-mail: olympia.papaevangelou@gmail.com

\begin{abstract}
Received: January 4, 2022 Accepted: January 28, 2022 Published: January 29, 2022
doi:10.5296/bms.v13i1.19430ＵRL: https://doi.org/10.5296/bms.v13i1.19430
\end{abstract}

\begin{abstract}
The global and fast-paced economy requires all types of businesses to cultivate their communication system for the efficient and smooth running of the organization. Various international crises can cause a shift towards a cheaper mode and methods of communication that can harm the overall business strategy and success. This study deals with the influence of strategic marketing approaches that can positively influence the communication quality and methods of a business. Particular emphasis has been put on business-to-customer communication targets along with new possibilities of developing more robust marketing communication tools. The paper aims to propose new approaches and trends in the current business-to-customer communication model that would help in mitigating both current and future challenges. Thereby, the paper incorporates pragmatism as research philosophy,
\end{abstract}


deductive as the research approach, and descriptive as the research design. Apart from that, a secondary method of data collection along with ethical modes of data collection is taken into consideration to present a comprehensive and efficacious paper.

Keywords: strategic marketing, business communication, social media marketing, strategic tools, and market research

\section{Introduction}

\subsection{Research Background}

The organization applies strategic marketing in business communication so that they can concentrate on its strength for delivering better services and value to its core customers. With the help of this strategic marketing, it will be beneficial for the organization to take things from a different aspect so that they can attract customer attention in a better way as compared to their competitors. Where to compete, how to compete, and when to compete are three questions that are involved in strategic marketing concepts. Earlier organizations used very basic marketing ideas but with time competition increased it encouraged organizations to improve strategic marketing concepts.

\subsection{Research Rationale}

In this research, the researcher studied the influence of strategic marketing approaches in business communication. The benefits of strategic marketing in the organization and how it helps them to increase their service quality so they attract mass audiences are identified. Also, the strategy is completely based on customers' approach and it helps in developing marketing campaigns which increase the brand value of the organization. Concepts like marketing research, social media marketing, promotional strategy, consumer behaviour and many more are applied through strategic marketing. While understanding consumer and market it is essential for the organization to implement strategic marketing which helps in creating marketing strategies to achieve the objectives and goals.

\subsection{Research Aim}

The aim of this research is to understand the factors that influence strategic marketing in business communication. Also, the different roles and advantages of strategic marketing are analyzed which help the organization to achieve goals and objectives.

\subsection{Research Objective}

- To identify the factors that influence strategic marketing in business communication.

- Understand strategic marketing plan components and benefits in business communication.

- Identify the advantages and disadvantages of strategic marketing.

- To analyze relationship marketing through business communication. 
1.5 Research Question

1. What are the different factors that influence strategic marketing in business communication?

2. How does strategic marketing plan components benefit business communication?

3. What are the advantages and disadvantages of strategic marketing?

4. What are the relationship marketing concepts in business communication?

\subsection{Significance of Research}

The importance of this research is to identify the different aspects of strategic marketing in the organization which help to accomplish goals and objectives. Strategic marketing also helps in developing brand value in the market which increases competition. It helps to connect the organization with customers directly as commented by Matuszyk \& Rymkiewicz (2018). Also, the quality of services and products are increased which help in fulfilling the demand and needs of customers. Innovation in business has increased and markets are penetrated with the help of strategic marketing. Newsletters, podcasts, social media, and emails are strategic marketing plans to communicate with their clients. Within a business, various departments are cooperated in creating a strategic marketing plan. The adequate relationship is developed between customers and companies so that the goals and objectives of the company are achieved.

\section{Methods and Theoretical Basis}

\subsection{Conceptual Framework}

Strategic marketing and business communication have a direct relationship in the organization. With the help of effective strategic marketing business communication is developed with a mass audience all over the world as commented by Key \& Czaplewski (2017). The promotional strategy, social media marketing, marketing research and many more are different concepts of strategic marketing which help the organization in implementing a marketing strategy. Also, the organization needs to plan adequate strategic marketing which benefits the business and develop brand value. The companies can also understand the requirements of customers effectively and deliver quality services so that it increases trust and loyalty.

\subsection{To Identify the Factors That Influence Strategic Marketing in Business Communication}

The factors that influence strategic marketing in business communication are explained below:

- With the help of strategic marketing, the cultural diversity was improved because in the organization different employees from different backgrounds are encouraged to give ideas and innovation which help the company to develop best plans. It helps the company to connect with different customers from different cultural backgrounds and easily fulfil the needs and demands of the customers as commented by Massiera et al. (2018). Also, it increases competition in the market and companies can grab opportunities which benefits to the business. 
- The consumer needs and wants are easily fulfilled with the help of strategic marketing. The company can easily connect with customers and take feedback from customers directly so that they can produce quality services. Also, it helps organizations to identify the ideal customers and understand their pain points effectively. Besides, it is a time-consuming task in understanding the needs and demands of customers but it is worthwhile. Even social media marketing is the best way to grab mass audiences all over the world.

- Strategic marketing helps the company to display and launch their products and services in a way that helps to look their products in front of customers in an innovative way. This increases competition in the market and products and services provide the best values in the market as commented by Waisbord (2020). Effective market research is done by the company and researched competitors products and services so that they can advertise their brands in an innovative way. This increases the customer's interest in that particular brand.

- It helped the company to maintain the market budget and smartly organized the advertising and promotion effectively which controlled the expenses of the company. Also, it saves the cost of the company so that they can produce products and services in the most effective way as commented by Chamberlin \& Boks (2018). For example, social media marketing is one of the most cost saving strategic marketing which helps the company to communicate with customers. Even the campaigns and posting done on social media is inexpensive and increases brand image in front of customers. It is the most innovative strategy to do marketing in the company.

\subsection{Understand Strategic Marketing Plan Components and Benefits in Business Communication}

The five main components are explained below:

\section{The positioning of the company}

Financially the firm current position is outlined. The planning team is allowed by analysis so that strategies are identified which help in achieving success. The company current situation is revealed by SWOT analysis so that companies strengths, weakness, opportunities, and threats.

\section{Goals and strategies}

The goals and strategies of the organizations are identified first then the strategic marketing plan is implemented. In production, distribution, and marketing of resources rationalization are informed by goals so that targets are converted into reality as commented by Jansson et al. (2017). The brand recognition is improved and desired results are achieved with the help of adequate media or promotion.

\section{Market opportunities}

Short term and long term opportunities are achieved and use the resources in an effective way 
so that opportunity is developed in the market as per the strategic marketing plan.

\section{Define target market}

The target groups are defined which is essential for products and services. The needs and demands, and even preference to capitalize on sales research is conducted through this step. These groups demographic and geographic stratification are defined.

\section{Marketing budget}

Strategic marketing plan is developed which also includes a realistic marketing budget and implements it in such a way that benefits the company. The responsibilities and duties are included in this and effective decision making is done.

\section{Strategic marketing planning benefits}

A plan is created through the process so that in an organization among all stakeholders common understanding is facilitated. The decision in management, towards institutional goals employees' behaviour and among current and potential clients responses are informed through this plan as commented by Lim \& Greenwood (2017). Over a period of time changes are developed in this plan which helps in meeting the objectives of the company through changing demands.

A corporate entity is allowed by a sound marketing plan so that market share grows and develops best outcomes which increase revenues and profits. With the help of an effective strategic marketing plan which benefits in operational costs and a larger economy in the market.

\subsection{Identify the Advantages and Disadvantages of Strategic Marketing}

\section{The advantages of strategic marketing are explained below:}

\section{Focused}

Strategic marketing sets allow the business to analyse and understand the content and this will help the organization to reach a mass audience. A plan and clear focus is given through strategic marketing. This will increase sales of the company and save the money of the company.

\section{The targets customers meet}

The engagement of customers is increased through strategic marketing. An offline and online strategic marketing is developed which integrates its business. The products are sold online by the company to increase the activity of the business and companies can effectively provide additional values to their customers as commented by Wang et al. (2018). Sales channels are diverse and business control is done by strategic marketing. 


\section{Unique businesses are introduced}

In marketing development, brand image is an essential part. This helps the company to convince the customers that this product is better than their competitor's products and encourage customers to buy their products and not from anyone else as commented by Ahmed (2016). Strategic marketing is created which introduces the business in a unique way and clear strategies are maps which increase communication.

\section{Disadvantages of strategic marketing which are explained below:}

Momentum is hard to generate: Strategic marketing is developed and takes time and it will take time for the growth of the company and it is difficult to implement strategic marketing. So it can be said that for the company momentum is generated, it is challenging as commented by Zatwarnicka-Madura et al. (2019). Even innovative ideas are developed and a skilled team is executed but success generation is difficult.

\section{Cost}

For a small business executing strategic marketing will charge extra cost and resources which will be disadvantaged.

\section{Weaknesses are exposed}

The company weaknesses are identified because of strategic marketing and it will be challenging to derail the vision of the company. If the data is not analyzed effectively the marketing decisions are difficult and unrealistic financial projections are created in an unrealistic way if the information is not interpreted effectively.

\section{Needs of the company}

Strategic marketing is developed information which is critical and this will be helpful only when the analysis is done effectively. So the needs of the company are fulfilled continuously if the data analysis is done properly.

\subsection{To Analyze Relationship Marketing Through Business Communication}

\section{Relationship marketing impacts on corporate culture}

In business developing trust is difficult to achieve and maintenance is also difficult. For a successful relationship marketing strategy, the recognition of the cultural implications is done by brands. Across all touchpoints, there should be realignment so that consistent positive customer experience is facilitated as commented by Brennan \& Merkl-Davies (2018). Collaboration and cooperation are difficult without culture and barriers will be created through departmental silos. This develops different information and customer experience are maximised across all channels.

Values and drives profitability are maximized through customer relationship marketing With the help of adequate collaboration and with customers interfacing are empowered and 


\section{Al Macrothink}

organizations use the resources so that problems are resolved. For customers, this helps in answering all questions so that positivity is provided which increases their experiences as commented by da Silva \& Casas (2017). The needs of customers are satisfied through brands with the help of positive experiences and provide effective products and services which develop values for customers. This increases customers satisfaction and profit for the company for a longer period of time.

\section{A relationship marketing strategy is to build}

Strategic marketing is built because of the data and information collected from different sources. This increases opportunities and challenges in the organization. In the first stage goals and objectives are developed with the help of strategic marketing which directly links with opportunity and challenge.

\subsection{Gap of Literature}

In this research, the researchers are unable to collect data through quantitative data analysis because of the pandemic situation all over the world. This will restrict the researcher and collect data from secondary or qualitative data analysis only as commented by Batova \& Andersen (2017). Also, due to limited time and cost in the research, researchers can collect information through online sources. Besides, researchers can also address information related to business communication which is not mentioned because of the time limit.

\subsection{Methodology}

\subsubsection{Research Onions}

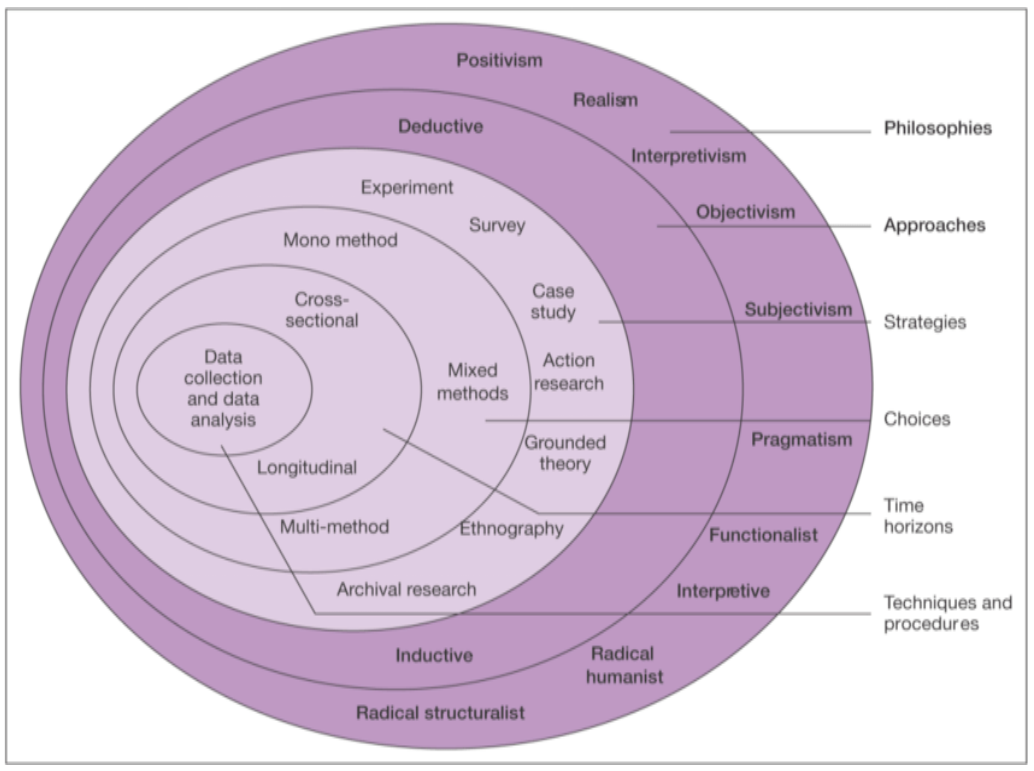

Figure 1: Research onion

(Source: Parida et al. 2019) 


\subsubsection{Research Philosophies}

Positivism helps the researcher to collect limited data and interpret it in an objective way. In this type of research, the data is observed by researchers effectively and statistical analysis is done through this research. From human experiences, the knowledge is grabbed in this positivism research so that it ensures to develop information which develops the best outcomes as commented by Pavliuk \& Noda (2020). In this research how different factors of strategic marketing help in business communication are researched effectively so that readers get effective information regarding this subject and increase their skills and knowledge.

\subsubsection{Research Approach}

The natural deductive approach is closer and it is believed in tests and hypotheses. For developing best outcomes hypothetical effects are tested with the help of experimental design in this particular study. In this, with the help of theory, the researcher collects data and theories are tested in case of deductive approach. Without any theory, the researchers are unable to conduct deductive approaches. The adequate data are provided in the research with the help of this approach and create a systematic pattern which provides effective information.

\subsubsection{Research Design}

A variety of qualitative and quantitative methods are used in descriptive research design so that one or more variables are investigated. Any variables are unable to be controlled or manipulated by researchers instead of observing and measuring the variables as commented by Hunt (2018). Frequencies, trends, categories are identified in the research with the help of this design and considered as the aim of the research. Surveys, observation and case studies are different methods in descriptive design which help researchers to collect data. In this research, researchers chose qualitative method means from different case studies they design the research.

\subsubsection{Data Collection and Sample Size}

Secondary or qualitative data analysis is done in the research by researchers to collect data. The sources like google scholar, books, journals, and articles are selected to collect data. It helps researchers to create a theme in the research which is analysed adequately and provides necessary information for the research as commented by Filipova \& Tushynska (2017). The sample size in this research is also small and it helps the researcher to cover the relevant information for the research. With the help of secondary data analysis, the researcher can maintain the time and cost of the researcher and complete it within a limited time. The outcomes developed from this research also help to increase the knowledge and skills of the members involved in this research.

\subsubsection{Ethical Consideration}

The researcher ensures to collect information from relevant sources only and ensures to follow the rules and regulations of the code of conduct of research while collecting data. Also, 
researchers make sure that no participants will get harmed or hurt during research. Besides, readers get effective information through this research which helps in increasing their knowledge and skills as commented by Akbar et al. (2017). Even the researcher needs to maintain the quality of the research and develop the ebay outcomes which benefit the environment and society.

\section{Methods}

\subsection{Process of Data Analysis}

To conduct this research, detailed data analysis is implemented in order to acquire relevant and reliable data. That is why qualitative data is considered for completing the research as it aligns with the secondary research. Thereby, various sources such as financial reports, business reports, articles, websites, and peer-viewed journals are used for this process. In addition to that, these sources are also useful for collecting data and running a robust analysis to back the research with adequate information. It also helps in ensuring that the data falls in alignment between literature and research objectives. The data and analysis have effectively described and explained the influence of strategic marketing in business communications.

\subsection{Thematic Analysis}

As qualitative data is taken for the completion of this research, that is why thematic analysis has been used. This analysis is not only simple to use but can also be used in a flexible manner in accordance with the researcher's choice of the conceptual and theoretical framework. It allows for detailed and rich description of the data. Henceforth, four themes are stated below that further helps in achieving the objectives of the research.

\subsubsection{Theme 1: Marketing Learning}

According to Chamberlin and Boks (2018), it is a dynamic process that helps in acquiring marketing capabilities along with integrated new insight and knowledge that can effectively improve the business' understanding of the behaviour of the customer. This, in turn, assists in generating satisfaction throughout the target audience. This theme involves all the processes through which the business can accumulate knowledge that would lead to more robust and improved capabilities in terms of vital marketing activities that includes but not limited to channelling established relationships, building brand image, new product development, and responding to requirements of customers. As commented by Iankova et al. (2019), the new skills and knowledge gained via learning can enhance the innovative abilities of an organization which would ultimately improve their customer communication as well as the market environment.

\subsubsection{Theme 2: Goals and Strategies}

A strategic marketing approach can never be complete without prior identification of the strategies and goals of the organization that needs to be implemented. As stated by Anabila, P. (2020), this way, the plans will rationalize the distribution of resources in marketing, 
distribution, and production while the strategies would help discussions of successful conversion of the said targets into realities.

\subsubsection{Theme 3: Unique Brand Name and Cost}

According to Camilleri, M. A. (2018), any marketing strategy has its share of advantages and disadvantages. For instance, a strategic marketing approach of a business will help its customers understand why their product/service is better compared to the competitor's one. It helps in creating a unique brand name that the business can utilize to communicate with both customers and other companies. On the other hand, executing these successful strategic marketing approaches often take longer and more expensive than expected.

\subsubsection{Theme 4: Customer Interaction}

As stated by Chamberlin and Boks (2018), Relationship marketing includes the development of value, communications, and interactions as customer relationships are built as well as maintained. Therefore, the management of interactions lies at the core strategic marketing approach as it creates a dialogue between the business and the customer. Communications support this in-turn. Particular emphasis is paid to two-way communications as they are fundamental in enhancing as well as building both existing and potential customer relationships.

Table 1. Thematical analysis

\begin{tabular}{|c|c|c|c|c|}
\hline Sources & Theme 1 & Theme 2 & Theme 3 & Theme 4 \\
\hline $\begin{array}{l}\text { Chamberlin, L., \& } \\
\text { Boks, C. } \\
\text { Marketing } \\
\text { approaches for a } \\
\text { circular economy: } \\
\text { Using design } \\
\text { frameworks to } \\
\text { interpret online } \\
\text { communications. } \\
\text { Sustainability }\end{array}$ & $\begin{array}{l}\text { This study focuses } \\
\text { on ways through } \\
\text { which businesses } \\
\text { can provide circular } \\
\text { services and/or } \\
\text { products using } \\
\text { communications in } \\
\text { order to market } \\
\text { their offerings as } \\
\text { well as influence } \\
\text { the behaviour of the } \\
\text { consumers. }\end{array}$ & $\begin{array}{l}\text { The study also } \\
\text { suggests less binary } \\
\text { and conventional } \\
\text { approaches that can } \\
\text { help the organization } \\
\text { to design appropriate } \\
\text { goals and strategies. }\end{array}$ & $\begin{array}{l}\text { The study has } \\
\text { concluded that } \\
\text { designed } \\
\text { frameworks can help } \\
\text { in analyzing reliable } \\
\text { marketing strategies } \\
\text { that can create } \\
\text { unique brand names } \\
\text { while being } \\
\text { cost-effective. }\end{array}$ & $\begin{array}{l}\text { The study further } \\
\text { shows that customer } \\
\text { acceptance and value } \\
\text { proposition can } \\
\text { greatly affect the } \\
\text { economic model of } \\
\text { the business. }\end{array}$ \\
\hline $\begin{array}{l}\text { Iankova, S., Davies, } \\
\text { I., Archer-Brown, } \\
\text { C., Marder, B., \& } \\
\text { Yau, A. (2019). A } \\
\text { comparison of social } \\
\text { media marketing } \\
\text { between B2B, B2C } \\
\text { and mixed business } \\
\text { models. Industrial } \\
\text { Marketing } \\
\text { Management }\end{array}$ & $\begin{array}{l}\text { This study helps in } \\
\text { analyzing } \\
\text { marketing learning } \\
\text { in terms of social } \\
\text { media that can be } \\
\text { fundamentally used } \\
\text { both for } \\
\text { business-to-busines } \\
\text { s and } \\
\text { business-to-custom } \\
\text { er communication. }\end{array}$ & $\begin{array}{l}\text { The study states how } \\
\text { social media usage } \\
\text { can be crucial for a } \\
\text { business to set their } \\
\text { goals and objectives } \\
\text { in accordance with } \\
\text { customer } \\
\text { requirements. }\end{array}$ & $\begin{array}{l}\text { This study even } \\
\text { states that social } \\
\text { media channels and } \\
\text { communication can } \\
\text { be effectively used } \\
\text { by a business to } \\
\text { create their brand } \\
\text { name among the } \\
\text { target audience. }\end{array}$ & $\begin{array}{l}\text { Apart from that, the } \\
\text { study also showcases } \\
\text { the advantages of } \\
\text { social media } \\
\text { marketing for } \\
\text { developing a robust } \\
\text { communication } \\
\text { channel with the } \\
\text { target consumers. }\end{array}$ \\
\hline
\end{tabular}




\begin{tabular}{|c|c|c|c|c|}
\hline $\begin{array}{l}\text { Anabila, P. (2020). } \\
\text { Integrated } \\
\text { marketing } \\
\text { communications, } \\
\text { brand equity, and } \\
\text { business } \\
\text { performance in } \\
\text { micro-finance } \\
\text { institutions: An } \\
\text { emerging market } \\
\text { perspective. Journal } \\
\text { of Marketing } \\
\text { Communications }\end{array}$ & $\begin{array}{l}\text { The study } \\
\text { concludes that } \\
\text { marketing learning } \\
\text { is always positively } \\
\text { related to } \\
\text { communication } \\
\text { strategy. } \\
\text { collaboration } \\
\text { between the two } \\
\text { acts as the main } \\
\text { driving force of } \\
\text { business success. }\end{array}$ & $\begin{array}{l}\text { In addition to that, } \\
\text { the study showcases } \\
\text { how difficult it can } \\
\text { be for a business to } \\
\text { generate momentum } \\
\text { using marketing } \\
\text { strategies. It also } \\
\text { throws light on the } \\
\text { financial constraints } \\
\text { of following a } \\
\text { marketing approach. }\end{array}$ & $\begin{array}{l}\text { The study rightfully } \\
\text { shows the } \\
\text { importance of IMC } \\
\text { (Integrated } \\
\text { Marketing } \\
\text { Communications) } \\
\text { plays a vital role in } \\
\text { improving brand } \\
\text { performance. }\end{array}$ & $\begin{array}{l}\text { It shows that } \\
\text { integrated } \\
\text { communications can } \\
\text { bring value in the } \\
\text { customer } \\
\text { relationships and } \\
\text { help in retaining } \\
\text { them throughout } \\
\text { business operations. }\end{array}$ \\
\hline $\begin{array}{l}\text { Camilleri, M. A. } \\
\text { (2018). Integrated } \\
\text { marketing } \\
\text { communications. In } \\
\text { Travel marketing, } \\
\text { tourism economics } \\
\text { and the airline } \\
\text { product }\end{array}$ & $\begin{array}{l}\text { The study states } \\
\text { that integrated } \\
\text { marketing } \\
\text { communications } \\
\text { along with other } \\
\text { promotional tools } \\
\text { through marketing } \\
\text { learning can } \\
\text { improve the overall } \\
\text { marketing strategy } \\
\text { of a business. }\end{array}$ & $\begin{array}{l}\text { There are various } \\
\text { effective plans that } \\
\text { are suggested by the } \\
\text { study for promoting } \\
\text { business } \\
\text { communications } \\
\text { while meeting other } \\
\text { business } \\
\text { requirements. }\end{array}$ & $\begin{array}{l}\text { The study further } \\
\text { suggests various } \\
\text { tools that can be } \\
\text { used as an advantage } \\
\text { for increasing the } \\
\text { awareness of the } \\
\text { company's service } \\
\text { and products and } \\
\text { inform consumers } \\
\text { about the same. }\end{array}$ & $\begin{array}{l}\text { The study suggests } \\
\text { that marketing } \\
\text { individuals must } \\
\text { take into } \\
\text { consideration the } \\
\text { factor of customer } \\
\text { interaction when } \\
\text { they are planning for } \\
\text { strategic marketing } \\
\text { approaches for } \\
\text { building } \\
\text { communications. }\end{array}$ \\
\hline \begin{tabular}{lr} 
Massiera, & P., \\
Gilmore, A., \& & Aellami, M. \\
(2018). \\
Marketing \\
illegitimacy & within \\
SMEs: & learning \\
triggers & and \\
influence & on \\
marketing & \\
communications. \\
Journal of Strategic \\
\multicolumn{2}{l}{ Marketing }
\end{tabular} & $\begin{array}{l}\text { The study indicates } \\
\text { how SME } \\
\text { managers and } \\
\text { owners can use } \\
\text { marketing learning } \\
\text { to understand the } \\
\text { usefulness of } \\
\text { various marketing } \\
\text { practices and } \\
\text { principals. }\end{array}$ & $\begin{array}{l}\text { It showcases that } \\
\text { negative perceptions } \\
\text { in terms of } \\
\text { marketing can } \\
\text { decrease when the } \\
\text { negative } \\
\text { performance } \\
\text { increases. }\end{array}$ & $\begin{array}{l}\text { The study highlights } \\
\text { that brands can } \\
\text { utilize effective } \\
\text { communication } \\
\text { channels for building } \\
\text { a robust presence } \\
\text { throughout the target } \\
\text { audience. }\end{array}$ & $\begin{array}{l}\text { The study also states } \\
\text { that customer } \\
\text { interaction can } \\
\text { create a meaningful } \\
\text { relationship between } \\
\text { the business and the } \\
\text { customers. }\end{array}$ \\
\hline
\end{tabular}

\subsection{Discussion}

From the above thematic analysis, it can be justified that strategic marketing approaches have a key influence on the development of business communications. It can effectively help the business to increase its overall performance. This way the business can offer better services and/or products to the customers. Apart from that, strategic marketing approaches allow the business to communicate with customers and understand their needs and requirements efficiently. This would help the business to fulfil such requirements easily without facing any major challenges. Thereby, the business can easily increase their brand loyalty including both existing and potential customers as well as formulate and develop a strong and healthy relationship with them. Various aspects of business such as goals and strategies are supported by strategic marketing approaches that further helps in understanding strategic planning 
components and the benefits of having a robust business communication channel. Customer relationship management is formulated through a strategic marketing approach along with marketing learning that provides reliable and adequate solutions needed for improving the quality of products and services. A deeper and meaningful connection is built between the business and the customers that not only encourages the customer engagement but also inspires their buying behaviour in favor of the said respective brand.

Strategic marketing approaches improve the skills and knowledge of the organization's management. It improves the experience of the business on how to handle their customers. Apart from that, through business communications, businesses are provided with the opportunity to analyze various aspects of the requirements of customers through the selected approaches. Thereby, all types of customer behavior can be enhanced in favor of the business and effectively resolve any challenges that the customers are facing. Moreover, businesses can also identify the various disadvantages and advantages of a specific marketing approach and check whether it fits their goals and objectives or not. It also assists them in tracking the various movements of customers while analyzing relationship marketing marketing via business communications. Through this, the business can not only increase its profit via vast quantities, but they can also develop a new and more improved infrastructure while considering the customers emotions. However, it should be a two-way communication between the customers and the businesses that can add more value to their relationship and evaluate the existing business operation in the most efficacious manner.

\section{Conclusion}

\subsection{Conclusion}

Based on the above discussion it can be concluded that the organizations required different factors of strategic marketing which benefits in business communication. The brand value of the organization is developed with the help of strategic marketing and value of products and services are increased which develop trust and loyalty between customer and companies. Besides, the quality of services is improved through strategic management so that companies can fulfil the needs of the customers. Even long term and short term goals of the business is achieved and develop a culture in the organization.

\subsubsection{Linking With Objectives}

The objectives of this research are completely fulfilled and information provided in this research is completely related to the objective of the research. While collecting data from different sources the researcher ensures that it will link with the objectives of the research. Even research questions formed in the research are related to the objective. The main aim of the researcher is to develop the outcomes which fulfil the research objectives and in this research, they achieve their objectives.

\subsubsection{Recommendations}

From the above discussion, it can be said that researchers can provide more information on 
strategic marketing which help in developing business communication. The external and internal environment of the organization is affected in what way should also be explained which help researchers to gain their knowledge and skills in this aspect also. The information provided in the research is effective but if the researcher collects information through other sources like qualitative methods it helps them to provide more information in a systematic way.

\subsubsection{Research Limitations}

Due to covid-19 pandemic situation, the researchers are unable to collect information through primary methods. This restricts the researcher from collecting data and they need to provide information from limited sources. Also, through primary sources, interviews and surveys can be conducted which can help researchers to understand the subject in an effective way. Besides due to time limit the researcher cannot go through all articles and books and online sources and chose limited sources for collecting information.

\subsubsection{Future Scope}

With the help of this research, the population can understand the importance of strategic marketing in today's world. In future business will grow so the industry will grow which will inspire organizations in every sector to adopt this strategy in marketing for continuous improvement. This helps the organization to provide new ideas and innovation and increase creativity which ultimately helps in maintaining the continuity in business. The more people communicate with each other the more they get to know which help to deliver the best quality products in the market.

\section{References}

Ahmed, R. R. (2016). „Strategic Marketing Plan of Nike“. ResearchGate, Indus Institute of Higher Education. Retrieved on: 15 September 2020; retrieved from https://10.13140/RG.2.1.1558.3122

Akbar, F., Omar, A., \& Wadood, F. (2017). The Niche Marketing Strategy Constructs (Elements) and its Characteristics-A Review of the Relevant Literature. Galore International Journal of Applied Sciences \& Humanities, 1(1), 73-80. Retrieved on: 15 September 2020; retrieved from https://dx.doi.org/10.2139/ssrn.2957004

Anabila, P. (2020). Integrated marketing communications, brand equity, and business performance in micro-finance institutions: An emerging market perspective. Journal of Marketing Communications, 26(3), 229-242. Retrieved on: 15 September 2020; retrieved from https://doi.org/10.1080/13527266.2019.1574868

Anabila, P. (2020). Integrated marketing communications, brand equity, and business performance in micro-finance institutions: An emerging market perspective. Journal of Marketing Communications, 26(3), 229-242. Retrieved on: 15 September 2020; retrieved from https://doi.org/10.1080/13527266.2019.1574868

Batova, T., \& Andersen, R. (2017). A systematic literature review of changes in roles/skills in 
component content management environments and implications for education. Technical Communication Quarterly, 26(2), 173-200. Retrieved on: 15 September 2020; retrieved from https://doi.org/10.1080/10572252.2017.1287958

Brennan, N. M., \& Merkl-Davies, D. M. (2018). Do firms effectively communicate with financial stakeholders? A conceptual model of corporate communication in a capital market context. Accounting and Business Research, 48(5), 553-577. Retrieved on: 15 September 2020; retrieved from https://doi.org/10.1080/00014788.2018.1470143

Camilleri, M. A. (2018). Integrated marketing communications. In Travel marketing, tourism economics and the airline product (pp. 85-103). Springer, Cham. Retrieved on: 15 September 2020; retrieved from https://doi.org/10.1007/978-3-319-49849-2_5

Chamberlin, L., \& Boks, C. (2018). Marketing approaches for a circular economy: Using design frameworks to interpret online communications. Sustainability, 10(6), 2070. Retrieved on: 15 September 2020; retrieved from https://doi.org/10.3390/su10062070

Da Silva, E. C., \& Casas, A. L. L. (2017). Sports ecosystems: Assumptions for incorporating marketing strategies in sports clubs. The Marketing Review, 17(4), 409-426. Retrieved on: 15 September 2020; retrieved from https://doi.org/10.1362/146934717X14909733966281

Filipova, L., \& Tushynska, V. (2017). Investigation of advantages and disadvantages of market economy. Technology audit and production reserves, $6(5$ (38)), 51-57. Retrieved on: 15 September 2020; retrieved from https:// 10.15587/2312-8372.2017.119537

Hunt, S. D. (2018). Advancing marketing strategy in the marketing discipline and beyond: from promise, to neglect, to prominence, to fragment (to promise?). Journal of Marketing Management, 34(1-2), 16-51. Retrieved on: 15 September 2020; retrieved from: https://doi.org/10.1080/0267257X.2017.1326973

Iankova , S., Davies, I., Archer-Brown, C., Marder, B., \& Yau, A. (2019). A comparison of social media marketing between B2B, B2C and mixed business models. Industrial Marketing Management, 81, 169-179. Retrieved on: 15 September 2020; retrieved from: https://doi.org/10.1016/j.indmarman.2018.01.001

Iankova, S., Davies, I., Archer-Brown, C., Marder, B., \& Yau, A. (2019). A comparison of social media marketing between B2B, B2C and mixed business models. Industrial Marketing Management, 81, 169-179. Retrieved on: 15 September 2020; retrieved from https://doi.org/10.1016/j.indmarman.2018.01.001

Jansson, J., Nilsson, J., Modig, F., \& Hed Vall, G. (2017). Commitment to sustainability in small and medium-sized enterprises: The influence of strategic orientations and management values. Business Strategy and the Environment, 26(1), 69-83. Retrieved on: 15 September 2020; retrieved from https://doi.org/10.1002/bse.1901

Kalogiannidis, S., Melfou, K., \& Papaevangelou, O. (2020). Global Marketing Strategic Approaches on Multi National Companies Product Development. International Journal of 
Scientific Research and Management, 8(12),

2084-2090. https://doi.org/10.18535/ijsrm/v8i12.em08

Kalogiannidis, S. (2021). The Effects of Total Quality Management Practices and Marketing on Performance of SMEs. A Case of Selected Manufacturing Industries, Greece. Business Management and Strategy, ISSN 2157-6068, 12(1), 48-62. doi:10.5296/bms.v12i1.17995

Kalogiannidis, S., \& Mavratzas, S (2020). Impact of marketing mix strategies effective product development issues in MNCs/Retail. International Journal of Business Marketing and Management (IJBMM), 5(12), December 2020, 118-125. ISSN: 2456-4559.

Key, T. M., \& Czaplewski, A. J. (2017). Upstream social marketing strategy: An integrated marketing communications approach. Business Horizons, 60(3), 325-333. Retrieved on: 15 September 2020; retrieved from: https://doi.org/10.1016/j.bushor.2017.01.006

Kontogeorgos, A, Chatzitheodoridis F, Loizou E. (2016). Adaptation Strategies for the Greek Agricultural Cooperatives during the Economic Crisis. Agricultural Economics, 62(1), 26-34. Retrieved on: 15 September 2020; retrieved from https://doi.org/10.17221/22/2015-AGRICECON

Lim, J. S., \& Greenwood, C. A. (2017). Communicating corporate social responsibility (CSR): Stakeholder responsiveness and engagement strategy to achieve CSR goals. Public Relations Review, 43(4), 768-776. Retrieved on: 15 September 2020; retrieved from https://doi.org/10.1016/j.pubrev.2017.06.007

Massiera, P., Gilmore, A., \& Sellami, M. (2018). Marketing illegitimacy within SMEs: learning triggers and influence on marketing communications. Journal of Strategic Marketing, 26(8), 688-701. Retrieved on: 15 September 2020; retrieved from https://doi.org/10.1080/0965254X.2017.1384036

Matuszyk, I., \& Rymkiewicz, B. (2018). Integrated Reporting as a Tool for Communicating with Stakeholders-Advantages and Disadvantages. In E3S Web of Conferences (Vol. 35, p. 06004). EDP Sciences. https://doi.org/10.1051/e3sconf/20183506004

Papaevangelou, O. (2021). Crisis management and theories in education. International Journal of Multidisciplinary Research and Growth Evaluation, 2(1), 127-130. ISSN: 2582-7138. https://www.allmultidisciplinaryjournal.com/archives/2021.v2.i1

Parida, V., Sjödin, D., \& Reim, W. (2019). Reviewing literature on digitalization, business model innovation, and sustainable industry: Past achievements and future promises. Retrieved on: 15 September 2020; retrieved from https://doi.org/10.3390/su11020391

Pavliuk, T., \& Noda, V. (2020). Analysis of competitiveness and competitive advantages in today's market conditions. Management and Entrepreneurship: Trends of Development, 2(12), 91-104. Retrieved on: 15 September 2020; retrieved from https://doi.org/10.26661/2522-1566/2020-2/12-07 


\section{Macrothink}

Waisbord, S. (2020). Family tree of theories, methodologies, and strategies in development communication. Handbook of Communication for Development and Social Change, 93-132. Retrieved on: 15 September 2020; retrieved from https://doi.org/10.1007/978-981-15-2014-3_56

Wang, Y., Kung, L., \& Byrd, T. A. (2018). Big data analytics: Understanding its capabilities and potential benefits for healthcare organizations. Technological Forecasting and Social Change, 126, 3-13. Retrieved on: 15 September 2020; retrieved from https://doi.org/10.1016/j.techfore.2015.12.019

Zatwarnicka -Madura, B., Siemieniako, D., Glińska, E., \& Sazonenka, Y. (2019). Strategic and operational levels of CSR marketing communication for sustainable orientation of a company: A case study from Bangladesh. Sustainability, 11(2), 555. Retrieved on: 15 September 2020; retrieved from https://doi.org/10.3390/su11020555

\section{Copyright}

Copyright for this article is retained by the author(s), with first publication rights granted to the journal.

This is an open-access article distributed under the terms and conditions of the Creative Commons Attribution license (http://creativecommons.org/licenses/by/4.0/). 